\title{
Performance Analysis of Screw Turbine Design with Additional Flaps Modification Using Computational Fluid Dynamics Method
}

\author{
Juniarko Prananda ${ }^{1}$, Eddy S. Koenhardono ${ }^{2}$, Noerendik F. Farhan ${ }^{3}$ \\ (Received: 26 August 2021 / Revised: 21 December 2021 / Accepted: 24 December 2021)
}

\begin{abstract}
Wind energy is one of the renewable energy sources. Because of Indonesia's equatorial location, the wind characteristics are moderate, with wind direction and speed changing frequently. To harvest wind energy, it is therefore vital to diversify the types of wind turbines. A screw turbine, also known as an Archimedes screw turbine or a screw turbine, is a type of wind turbine that is often employed in micro hydropower plants. The great efficiency of this turbine is a benefit. This screw turbine will use a Horizontal Axis Wind Turbine (HAWT). The advantage of using the horizontal axis over the vertical axis is that the rotor's efficiency is higher. The screw turbine was changed in this study by adding flaps to boost torque and rpm performance while also increasing wind catchment. The model design with the inclusion of $3 \mathrm{~cm}$ flaps with a flap angle of $30^{\circ} \mathrm{has}$ a high torque and angular velocity with a torque value of $0.00609 \mathrm{Nm}$ and an angular velocity of $12.55 \mathrm{rad} / \mathrm{s}$ at an airflow velocity of $3.4 \mathrm{~m} / \mathrm{s}$, according to the results obtained from model simulation using CFD $(119,84 \mathrm{RPM})$. Power Coefficient $(\mathrm{CP})=$ 0.00659, Torque Coefficient $(C Q)=0.01990$, and Tip Speed Ratio $($ TSR $)=0.331357$.
\end{abstract}

Keywords-flaps, power coefficient, screw turbine, tip speed ratio, torque coefficient.

\section{INTRODUCTION}

$\mathrm{R}$ enewable energy is an alternative energy source that can be used to produce electrical energy sources. Wind energy is one of the renewable energy sources. Because of Indonesia's equatorial location, the wind characteristics are moderate, with wind direction and speed changing frequently. To harvest wind energy, it is therefore vital to diversify the types of wind turbines. A screw turbine, also known as an Archimedes screw turbine (AST) or an Archimedes Screw Generator (ASG), is a type of wind turbine widely employed in mini-hydropower plants. The use of screw turbines for micro-hydropower plants is used because it has high efficiency. Several experimental studies on screw turbines have shown that high efficiency can be achieved and maintained by regulating the flow of water entering the turbine [1][2]. Based on screw turbine data showing high efficiency, an Archimedes Screw Generator (ASG) developed by Prof. Hiroshi Takimoto the resulting efficiency is $60 \%$ [3]. ASG can produce an operational efficiency of $80 \%$ [4]. At ASG commercial installations in Europe, the average operational efficiency is 69\% with a maximum efficiency of more than $75 \%$ [5]. Having high efficiency is an advantage of this microhydro turbine.

Juniarko Prananda is with Departement of Marine Engineering, Institut Teknologi Sepuluh Nopember, Surabaya, 69111, Indonesia. Email: juniarko.prananda@gmail.com

Eddy Setyo Koenhardono is with Departement of Marine Engineering, Institut Teknologi Sepuluh Nopember, Surabaya, 69111, Indonesia. E-mail: eddy-k@its.ac.id

Noerendik Fuathur Farhan is with Departement of Marine Engineering, Institut Teknologi Sepuluh Nopember, Surabaya, 69111, Indonesia. E-mail: noerendikfarhan1199@gmail.com
This screw turbine will use a Horizontal Axis Wind Turbine (HAWT). The use of the horizontal axis has the advantage that the efficiency of the rotor is higher than the vertical type, the turbine can be directed in the direction of the wind and has a protective mechanism against damaging winds [6]. So that the use of this type of horizontal axis turbine on a screw turbine is considered appropriate to obtain optimal efficiency. With the difference in the density of water and air, it is necessary to make additional modifications to increase torque and rpm performance and more wind catchment power, one way that can be used is the addition of flaps. In this study, the screw turbine will be modified by adding flaps on the turbine thread in order to improve the performance of this turbine in extracting wind energy. The addition of flaps on the aircraft serves to direct the airflow so that it is proven to be able to provide an additional lift on the aircraft [7]. Therefore, the application of the addition of flaps will be analyzed for its performance in this research. The performance of this screw turbine can be done using the method Computational Fluid Dynamics. Based on the background that has been described, the objectives of this research are as follows:

1) Achieve the simulation design of the screw turbine so that it can extract wind energy

2) Achieve the performance of the design screw turbine with the addition of flaps using the method Computational Fluid Dynamics

\section{A. Wind Energy}

The wind is the air that moves as a result of differences in air pressure, air flows from higher pressure to lower air pressure. Differences in air pressure can occur due to differences in air temperature due to uneven heating of the atmosphere by the sun [8]. 


\section{B. Wind Turbine}

A wind turbine is a device used to convert wind power into electricity [9]. The mechanical energy produced by the wind moves a turbine which is connected to a generator so that it can produce electricity. Wind turbines are divided into 2 types based on the direction of the rotor axis, namely Horizontal Axis Wind Turbine (HAWT) and Vertical Axis Wind Turbine (VWAT).

Wind turbines that have more than 3 blades with high solidity have a large torque. Meanwhile, wind turbines with a number of blades less than 3 have low torque but high rotor rotation [8]. In this study using HAWT, the use of the horizontal axis has advantages, namely the efficiency produced by the rotor is higher when compared to the vertical type, the turbine can be directed to the direction of the wind and has a protective mechanism against damaging winds [6].

\section{Flaps Turbine}

Flaps are the rear of the aircraft wing that functions to circulate air so as to provide an additional lift on the aircraft at low speeds [7]. In this study, flaps are used to provide wind extract, direct fluid flow to pass through the turbine threads and increase turbine force lift.

\section{Computational Fluid Dynamics}

Computational Fluid Dynamics (CFD) is a method used to find numerical solutions related to fluid flow equations with the help of computers. By using CFD the fluid flow around the turbine can be used to predict the behaviour of the turbine with the wind. The results and information obtained from CFD can be used to develop the performance of the screw turbine.

\section{E. Turbine Performance Parameter}

To determine the performance of the turbine can use the Power Coefficient (Cp), Torque Coefficient (TSR), and Tip Speed Ratio (TSR). Cp which is the aerodynamic efficiency of the turbine can be calculated by the ratio of the power generated by the rotor compared to the available power of the air-fluid as in equations 1 and 2 [10].

$$
\begin{aligned}
& \mathrm{Cp}=\frac{\text { Protor }[W]}{0.5 \rho A V^{3}[W]} \\
& \mathrm{P}_{\text {rotor }}[\mathrm{W}]=\mathrm{T}_{\text {rotor }}[\mathrm{Nm}] \cdot \omega_{\text {rotor }}[\mathrm{rad} / \mathrm{s}]
\end{aligned}
$$

Where:

$\mathrm{Cp}=$ Power Coefficient

$\mathrm{P}_{\text {rotor }} \quad=$ Power from rotor (watt)

$\rho \quad=$ Air density at $25^{\circ} \mathrm{C}, 1 \mathrm{~atm}\left(\mathrm{~kg} / \mathrm{m}^{3}\right)$

A $\quad=$ Area of turbine sweep $\left(\mathrm{m}^{2}\right)$

$\mathrm{T}=$ Torque from rotor turbine $(\mathrm{Nm})$

$\omega=$ Angular velocity rotor turbine ( $\mathrm{rad} / \mathrm{s})$

then the power that can be generated by the turbine can be obtained as in equation 3[10]

$\mathrm{P}=\frac{1}{2} \rho \mathrm{AV}^{3} \mathrm{Cp}$

Where:

$\mathrm{P} \quad=$ Power of actual rotor (watt)

$\mathrm{Cp} \quad=$ Power coefficient

$\rho \quad=$ Air density at $25^{\circ} \mathrm{C}, 1 \mathrm{~atm}\left(\mathrm{~kg} / \mathrm{m}^{3}\right)$

A $\quad=$ Area of turbine sweep $\left(\mathrm{m}^{2}\right)$

$\mathrm{V}=$ Wind speed $(\mathrm{m} / \mathrm{s})$

Power Coefficient $(\mathrm{Cp})$ is a function of the tip speed ratio. Where the tip speed ratio is the ratio between the rotational speed of the rotor and the wind speed as in equation 4[9].

$$
\lambda=\frac{R \Omega}{V_{\infty}}
$$

$$
\begin{array}{ll}
\lambda & =\text { Tip speed ratio } \\
\mathrm{R} & =\text { Radius of turbine }(\mathrm{m}) \\
\Omega & =\text { Angular velocity }(\mathrm{rad} / \mathrm{s}) \\
\mathrm{V} & =\text { Wind speed }(\mathrm{m} / \mathrm{s})
\end{array}
$$

The relationship between the power coefficient and the tip speed ratio can provide information about the maximum rotor power coefficient and the optimum tip speed ratio [13]. The following is an example of a curve power coefficient with a tip speed ratio Figure 1 [9].

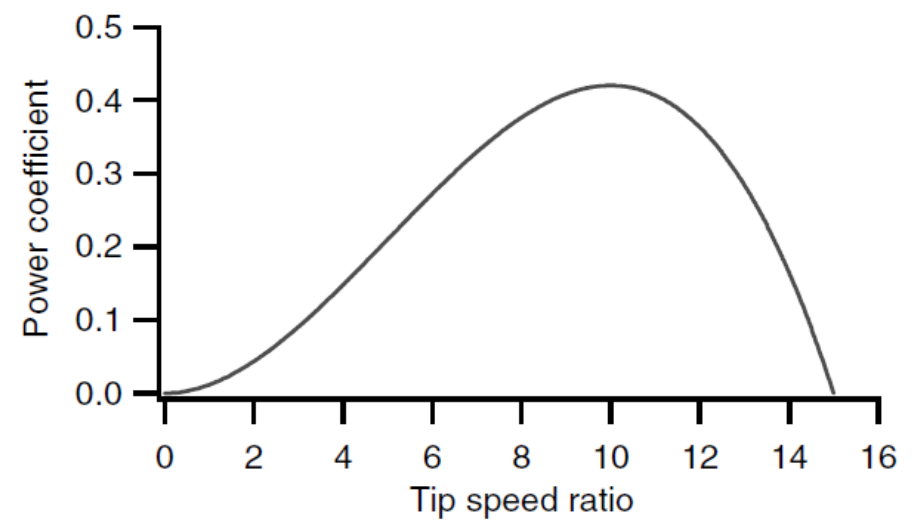

Figure. 1. Curve TSR vs Cp 
The torque coefficient is obtained from the power coefficient divided by the tip speed ratio as in equation 5 [9].

$$
C_{Q}=\frac{C_{p}}{\lambda}
$$

Where :

$$
\begin{array}{ll}
\mathrm{C}_{\mathrm{Q}} & =\text { Torque Coefficient } \\
\mathrm{C}_{\mathrm{P}} & =\text { Power Coefficient } \\
\lambda & =\text { Tip speed ratio }
\end{array}
$$

\section{METHOD}

\section{A. Description}

The Research method to be used is described in this chapter. Starting from the study literature to the performance analysis of the screw turbine simulation results.

\section{B. Flowchart Details}

1) Literature Study

A literature study is done by studying the basic theory that is useful to support this research. Studies on references related to screw turbines and their development as micro-hydro generators as well as references on wind turbines will then become the basis for the development of this screw turbine in order to extract wind. This literature is obtained from research journals, articles, textbooks, the internet, and another reference.

e with additional flaps $2 \mathrm{~cm}$ angle flaps $15^{\circ} \mathrm{can}$ be seen in Figure 3. Model 1 screw turbine with additional flaps $2 \mathrm{~cm}$ angle flaps $30^{\circ}$ can be seen in Figure 4. Model 1 screw turbine with additional flaps $2 \mathrm{~cm}$ angle flaps $45^{\circ}$ can be seen in Figure 5 . Model 1 screw turbine with additional flaps $3 \mathrm{~cm}$ angle flaps $15^{\circ}$ can be seen in Figure 6. Model 1 screw turbine with additional flaps $3 \mathrm{~cm}$ angle flaps $30^{\circ}$ can be seen in Figure 7. Model 1 screw turbine with additional flaps $3 \mathrm{~cm}$ angle flaps $45^{\circ}$ can be seen in Figure 8. The Model 2 screw turbine without flaps can be seen in Figure 9. Model 2 screw turbine with the additional flaps $2 \mathrm{~cm}$ angle flaps $15^{\circ} \mathrm{can}$ be seen in Figure 10. Model 2 screw turbine with additional flaps $2 \mathrm{~cm}$ flaps angle $30^{\circ}$ can be seen in Figure 11. Model 2 screw turbine with additional flaps $2 \mathrm{~cm}$ angle flaps $45^{\circ}$ can be seen in Figure 12 . Model 2 screw turbine with additional flaps $3 \mathrm{~cm}$ angle flaps $15^{\circ}$ can be seen in Figure 13. Model 2 screw turbine with additional flaps $3 \mathrm{~cm}$ angle flaps $30^{\circ}$ can be seen in Figure 14. Model 2 screw turbine with additional flaps $3 \mathrm{~cm}$ flaps angle $45^{\circ}$ can be seen in Figure 15.

\section{2) Problem Identification}

At this stage, the formulation of problems related to the background and object of research is carried out. Based on previous studies, it was found that screw turbines are widely used in micro-hydro plants but there has been no research on screw turbines being used as wind-powered power plants so there is no data on screw turbines in extracting wind and their performance. So the essence of the formulation of the problem in this research is to make a simulation design of the screw turbine so that it can extract wind and analyze the performance of the modified screw turbine.

\section{3) Screw Turbine Design}

Conceptually the design of the screw turbine that will be made consists of 2 models and both models consist of a model without flaps and with the addition of flaps. Parameters and model dimensions

\begin{tabular}{|c|c|c|c|c|c|c|}
\hline \multirow[b]{2}{*}{ Model Variation } & \multicolumn{6}{|c|}{ Parameters } \\
\hline & $\mathrm{D}(\mathrm{cm})$ & $\mathrm{d}(\mathrm{cm})$ & $\mathrm{n}$ & $\alpha\left(^{\circ}\right)$ & $\mathrm{L}(\mathrm{cm})$ & $\begin{array}{l}\text { Pitch } \\
(\mathrm{cm})\end{array}$ \\
\hline Model 1 & 30 & 3 & 3 & 60 & 50 & 12 \\
\hline Without Flaps & & & & & & \\
\hline $\begin{array}{l}\text { Model } 1 \text { Flaps } \\
2 \mathrm{~cm} 15^{\circ}\end{array}$ & 31.14 & 3 & 3 & 60 & 51.63 & 12 \\
\hline $\begin{array}{l}\text { Model } 1 \text { Flaps } \\
2 \mathrm{~cm} 30^{\circ}\end{array}$ & 32.10 & 3 & 3 & 60 & 51.43 & 12 \\
\hline $\begin{array}{l}\text { Model } 1 \text { Flaps } \\
2 \mathrm{~cm} 45^{\circ}\end{array}$ & 32.94 & 3 & 3 & 60 & 51.11 & 12 \\
\hline $\begin{array}{l}\text { Model 1 Flaps } \\
3 \mathrm{~cm} 15^{\circ}\end{array}$ & 31.66 & 3 & 3 & 60 & 52.60 & 12 \\
\hline $\begin{array}{l}\text { Model } 1 \text { Flaps } \\
3 \mathrm{~cm} 30^{\circ}\end{array}$ & 33.10 & 3 & 3 & 60 & 52.30 & 12 \\
\hline $\begin{array}{l}\text { Model } 1 \text { Flaps } \\
3 \mathrm{~cm} 45^{\circ}\end{array}$ & 34.34 & 3 & 3 & 60 & 51.82 & 12 \\
\hline $\begin{array}{l}\text { Model } 2 \\
\text { Without Flaps }\end{array}$ & 30 & 3 & 3 & 60 & 75 & 21.67 \\
\hline $\begin{array}{l}\text { Model } 2 \text { Flaps } \\
2 \mathrm{~cm} 15^{\circ}\end{array}$ & 31.14 & 3 & 3 & 60 & 76.63 & 21.67 \\
\hline $\begin{array}{l}\text { Model } 2 \text { Flaps } \\
2 \mathrm{~cm} 30^{\circ}\end{array}$ & 32.10 & 3 & 3 & 60 & 76.43 & 21.67 \\
\hline $\begin{array}{l}\text { Model } 2 \text { Flaps } \\
2 \mathrm{~cm} 45^{\circ}\end{array}$ & 32.98 & 3 & 3 & 60 & 76.14 & 21.67 \\
\hline $\begin{array}{l}\text { Model } 2 \text { Flaps } \\
3 \mathrm{~cm} 15^{\circ}\end{array}$ & 31.66 & 3 & 3 & 60 & 77.60 & 21.67 \\
\hline
\end{tabular}
of the screw turbine are shown in Table 1.

TABLE 1. PARAMETER AND DIMENSION DESIGN SCREW TURBINE MODEL 


\begin{tabular}{lllllll} 
Model 2 Flaps & 33.10 & 3 & 3 & 60 & 77.30 & 21.67 \\
$\begin{array}{l}3 \mathrm{~cm} 30^{\circ} \\
\text { Model 2 Flaps }\end{array}$ & 34.40 & 3 & 3 & 60 & 76.85 & 21.67 \\
$3 \mathrm{~cm} 45^{\circ}$ & & & & & & \\
\hline \hline
\end{tabular}

4) 3D Modelling Screw Turbine

At this stage created of a 3-dimensional design model of the screw turbine, the dimensions of the turbine are based on the parameters in determining the design screw turbine in the previous stage. Making this 3-dimensional turbine model using CAD software. Model 1 screw turbine without flaps can be seen in Figure 2. Model 1 screw turbine with additional flaps $2 \mathrm{~cm}$ angle flaps $15^{\circ}$ can be seen in Figure 3. Model 1 screw turbine with additional flaps $2 \mathrm{~cm}$ angle flaps $30^{\circ}$ can be seen in Figure 4 . Model 1 screw turbine with additional flaps $2 \mathrm{~cm}$ angle flaps $45^{\circ}$ can be seen in Figure 5. Model 1 screw turbine with additional flaps $3 \mathrm{~cm}$ angle flaps $15^{\circ}$ can be seen in Figure 6. Model 1 screw turbine with additional flaps $3 \mathrm{~cm}$ angle flaps $30^{\circ}$ can be seen in Figure 7. Model 1 screw turbine with additional flaps $3 \mathrm{~cm}$ angle flaps $45^{\circ}$ can be seen in Figure 8. The Model 2 screw turbine without flaps can be seen in Figure 9. Model 2 screw turbine with the additional flaps $2 \mathrm{~cm}$ angle flaps $15^{\circ} \mathrm{can}$ be

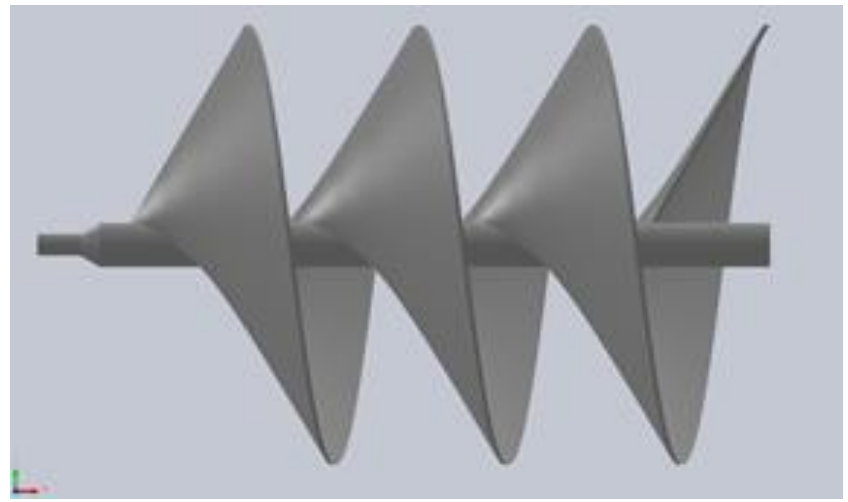

Figure. 2. Model 1 Without Flaps

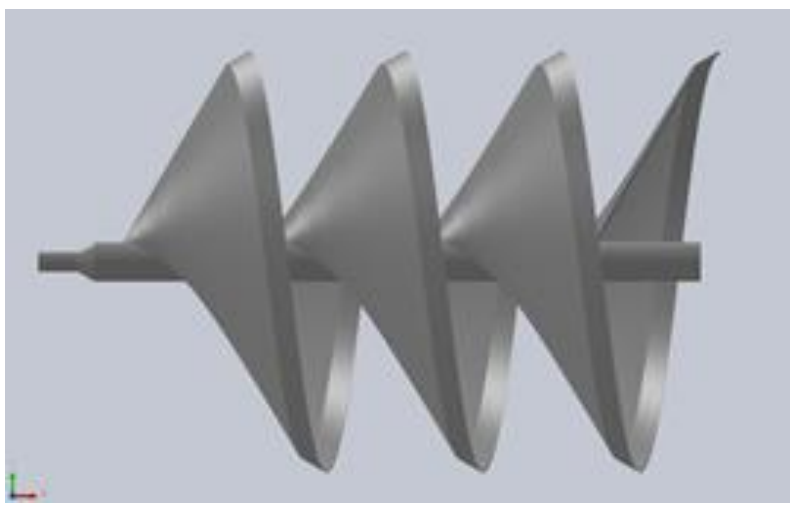

Figure. 4. Model 1 Flaps $2 \mathrm{~cm} 30^{\circ}$ seen in Figure 10. Model 2 screw turbine with additional flaps $2 \mathrm{~cm}$ flaps angle $30^{\circ}$ can be seen in Figure 11. Model 2 screw turbine with additional flaps $2 \mathrm{~cm}$ angle flaps $45^{\circ}$ can be seen in Figure 12 . Model 2 screw turbine with additional flaps $3 \mathrm{~cm}$ angle flaps $15^{\circ}$ can be seen in Figure 13. Model 2 screw turbine with additional flaps $3 \mathrm{~cm}$ angle flaps $30^{\circ}$ can be seen in Figure 14. Model 2 screw turbine with additional flaps $3 \mathrm{~cm}$ flaps angle $45^{\circ}$ can be seen in Figure 15.

\section{5) Simulation Model}

Simulation using CFD software with a model of a screw turbine, input fluid type, flow rate, dynamic viscosity, density. Before running the simulation, it is necessary to set settings, namely general parameters, fluid model, flow model, boundary conditions, body definition, body motion, mesh management, initial solution, control variables, and output parameters.

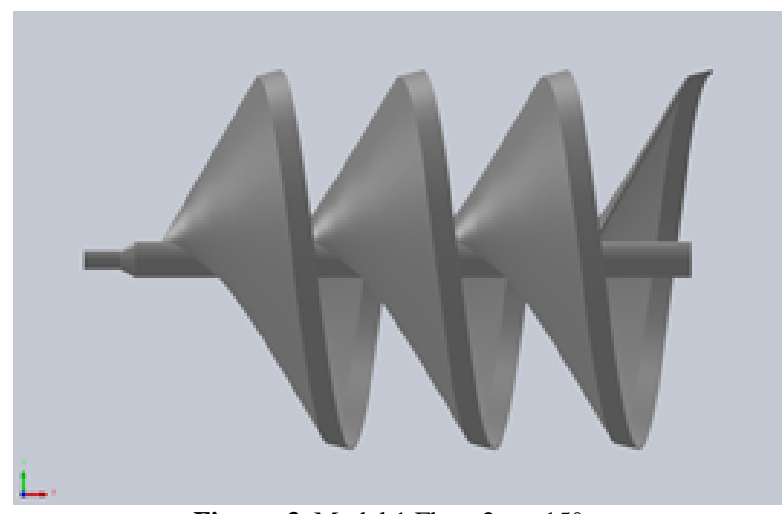

Figure. 3. Model 1 Flaps $2 \mathrm{~cm} 15^{\circ}$

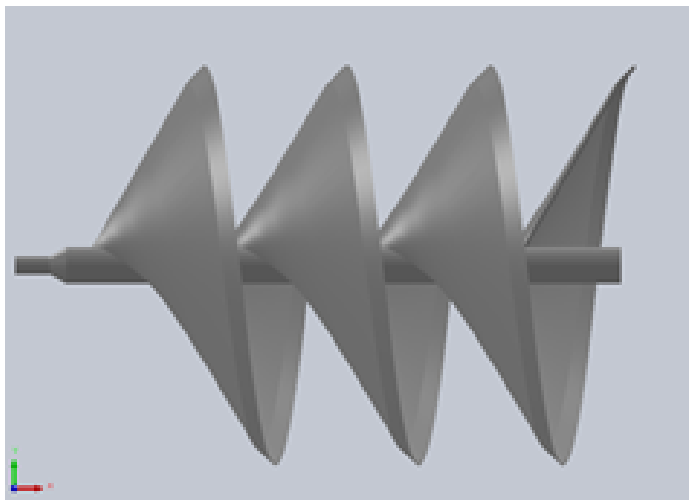

Figure. 5. Model 1 Flaps $2 \mathrm{~cm} 45^{\circ}$ 
International Journal of Marine Engineering Innovation and Research, Vol. 6(4), Dec. 2021. 246-254 (pISSN: 2541-5972, eISSN: 2548-1479)

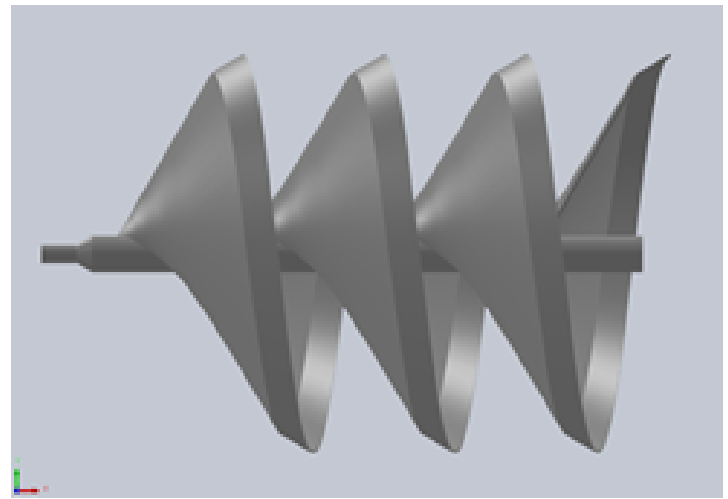

Figure. 6. Model 1 Flaps $3 \mathrm{~cm} 15^{\circ}$

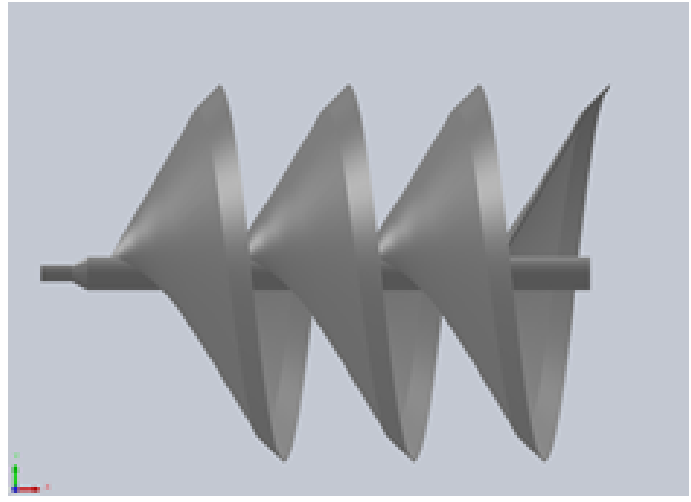

Figure. 8. Model 1 Flaps $3 \mathrm{~cm} 45^{\circ}$

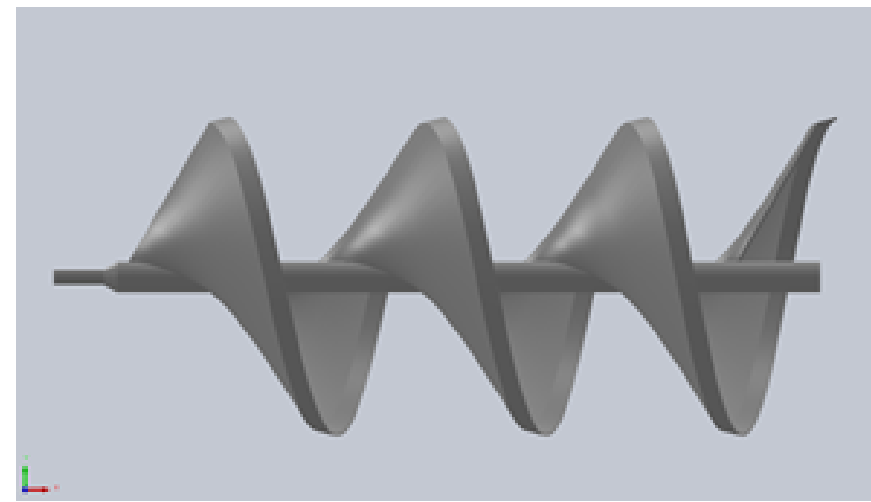

Figure. 10. Model 2 Flaps $2 \mathrm{~cm} 15^{\circ}$

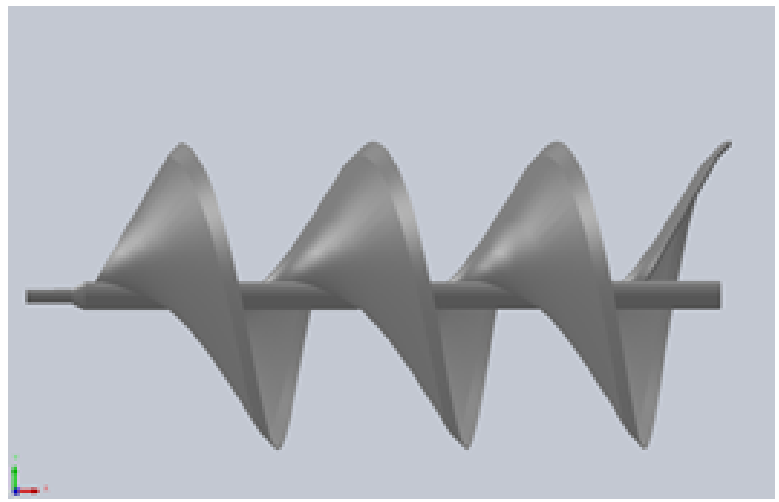

Figure. 12. Model 2 Flaps $2 \mathrm{~cm} 45^{\circ}$

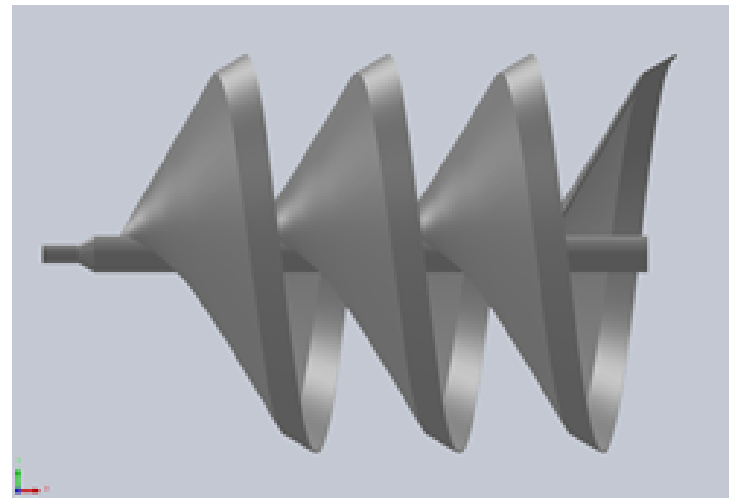

Figure. 7. Model 1 Flaps $3 \mathrm{~cm} 30^{\circ}$

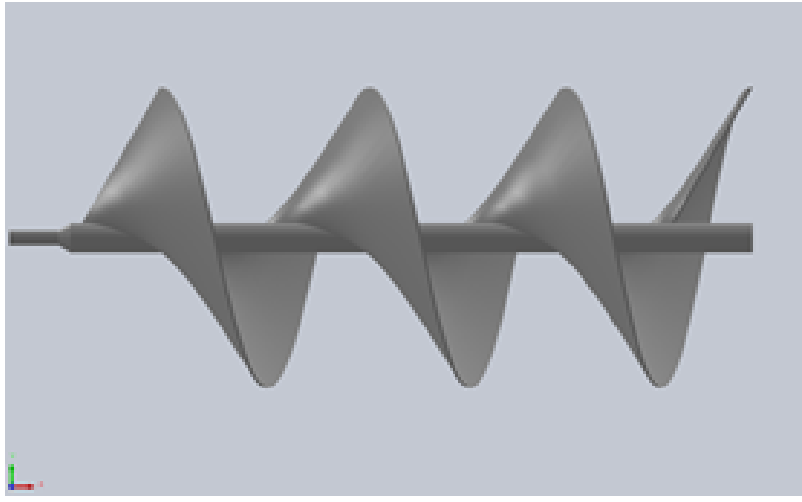

Figure. 9. Model 2 Without Flaps

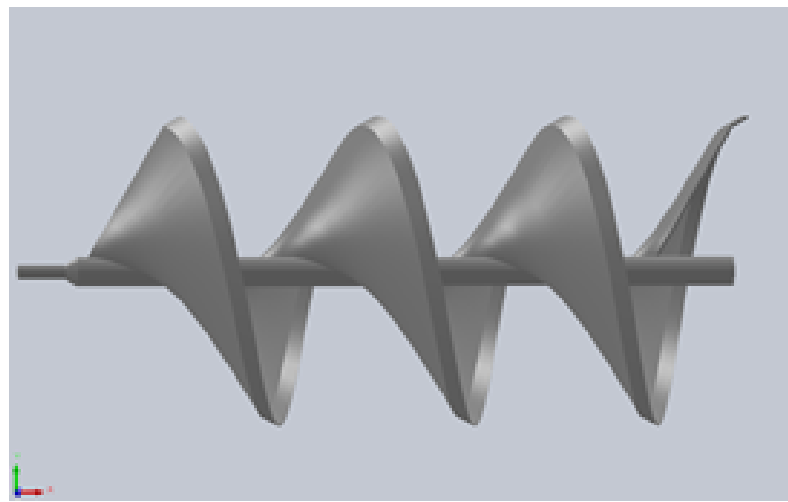

Figure. 11. Model 2 Flaps $2 \mathrm{~cm} 30^{\circ}$

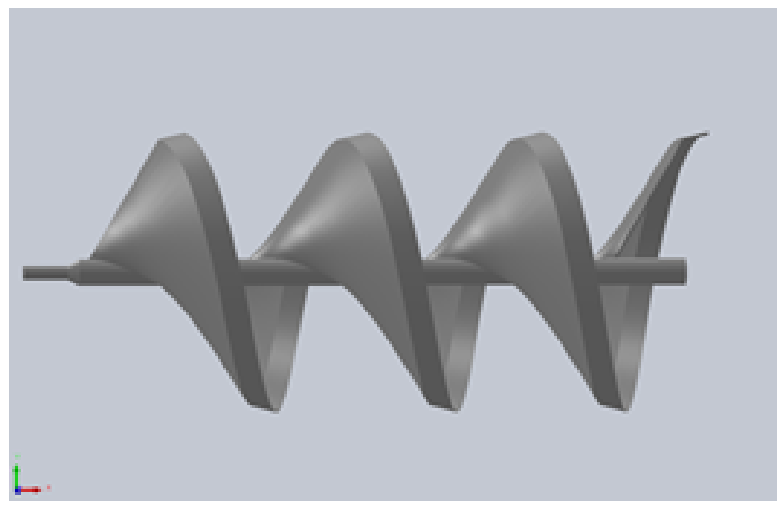

Figure. 13. Model 2 Flaps $3 \mathrm{~cm} 15^{\circ}$ 


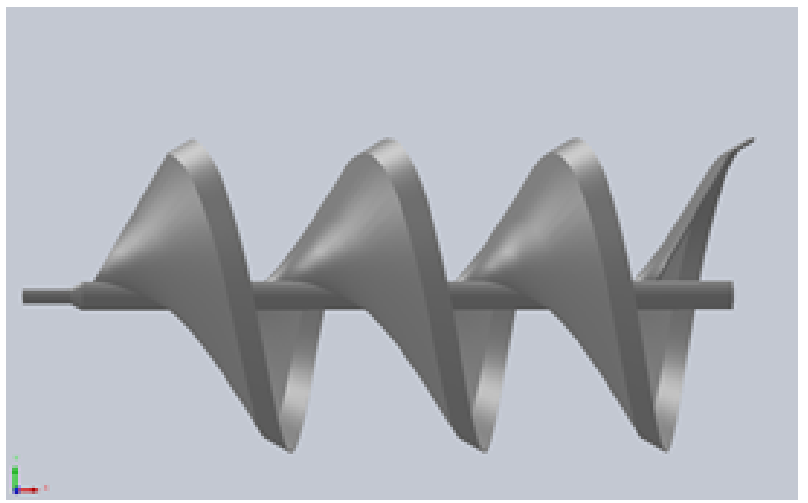

Figure. 14. Model 2 Flaps $3 \mathrm{~cm} 30^{\circ}$

6) Calculation and Performance Analysis of The Simulation Result Data

The analysis is carried out to determine whether the modified screw turbine can extract wind energy. If the model of this turbine can extract wind, the calculation of the simulation results in the form of torque and angular velocity obtained from the CFD simulation will be carried out. Torque and Angular Velocity will be used as input for calculating power (power), Power Coefficient (Cp), Torque Coefficient (CQ), and Tip Speed Ratio (TSR). In all simulated models, the results of this calculation will be plotted into a graph or table to see the difference in calculations from all simulated turbine models.

\section{RESULTS AND DISCUSSION}

\section{A. Result CFD Simulation}

The results of CFD simulations from each model and variations obtained are torque $(\mathrm{Nm})$ and motion (RPM). All simulation results in the form of torque and motion ( $\mathrm{rad} / \mathrm{s}$ or RPM) can be seen in Table 2, Figure 16, and Figure 17.

\section{B. Calculation Performance}

The simulation results have been obtained as input for the input calculation of power (power), Power Coefficient (Cp), Torque Coefficient (CQ), and Tip Speed Ratio (TSR). The results of the calculation of power, power coefficient, Torque coefficient (CQ), and Tip Speed Ratio (TSR) can be seen in Table 3. And the calculation of the power turbine can be seen in Figure 18.

\section{Comparative Analysis of Simulation Results} In model 1 with the addition of flaps when

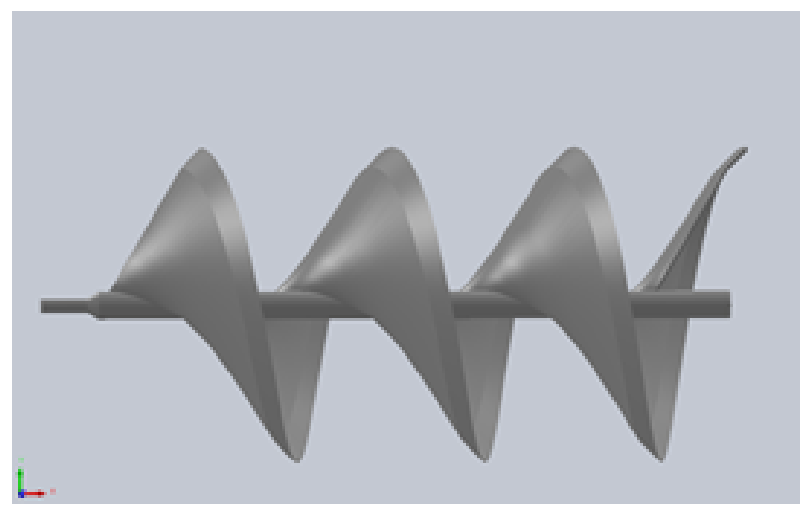

Figure. 15. Model 2 Flaps $3 \mathrm{~cm} 45^{\circ}$

compared to model 1 without flaps. Model 1 with the addition of flaps has a higher torque than without the addition of flaps. Model 2 with the addition of flaps, when compared to model 2 without flaps, has a higher torque. This means that the addition of flaps can increase the torque value on turbine models 1 and 2 .

In model 1 , the flaps with variations in the size of the flaps are $2 \mathrm{~cm}$ and $3 \mathrm{~cm}$. It was found that at 2 $\mathrm{cm}$ flaps the highest torque was at $30^{\circ}$ flaps angle variation with $0.00177 \mathrm{Nm}$ torque and $7.0190 \mathrm{rad} / \mathrm{s}$ rotation. While the size of the flap is $3 \mathrm{~cm}$, the highest torque is at the flap angle variation of $30^{\circ}$ with a torque of $0.00609 \mathrm{Nm}$ and a rotation of $12.55 \mathrm{rad} / \mathrm{s}$. This means that increasing the size of the flaps can increase the torque that will be generated.

In the 2 flaps model with variations in the size of the flaps $2 \mathrm{~cm}$ and $3 \mathrm{~cm}$. It was found that at $2 \mathrm{~cm}$ flaps the highest torque was at $45^{\circ}$ flaps angle variation with $0.00087 \mathrm{Nm}$ torque and $6.06598 \mathrm{rad} / \mathrm{s}$ rotation. While the size of the flap is $3 \mathrm{~cm}$, the highest torque is at $45^{\circ}$ flap angle variation with $0.00093 \mathrm{Nm}$ torque and $6,34528 \mathrm{rad} / \mathrm{s}$ rotation. This means that increasing the size of the flaps can increase the torque that will be generated.

Models 1 and 2 have the same number of threads as the 3 helix. But it has a turbine length difference, model 1 has a length of about $50 \mathrm{~cm}$ while model 2 has a length of $75 \mathrm{~cm}$ so that it affects the width of the pitch. If it is seen from the simulation results, the pitch size affects the torque produced, the model with a wide pitch has an effect on the decrease in torque. When viewed from the angle of the flaps, model 2 requires a wider flap angle to increase torque than model 1 which has a lower angle than model 2.

TABLE 2.

SIMULATION RESULTS SCREW TURBINE MODEL

\begin{tabular}{|c|c|c|c|c|}
\hline \multirow{2}{*}{ Model Variation } & \multirow{2}{*}{$\begin{array}{c}\text { Wind } \\
\text { Speed } \\
(\mathrm{m} / \mathrm{s})\end{array}$} & \multirow{2}{*}{$\begin{array}{c}\text { Torque } \\
\text { (Nm) }\end{array}$} & \multicolumn{2}{|c|}{ Motion } \\
\hline & & & $\mathrm{Rad} / \mathrm{s}$ & RPM \\
\hline Model 1 Without Flaps & 3.4 & 0.00085 & 9.15932 & 87.465 \\
\hline Model 1 Flaps $2 \mathrm{~cm} 15^{\circ}$ & 3.4 & 0.00121 & 7.12347 & 68.024 \\
\hline Model 1 Flaps $2 \mathrm{~cm} 30^{\circ}$ & 3.4 & 0.00177 & 7.01940 & 67.030 \\
\hline Model 1 Flaps $2 \mathrm{~cm} 45^{\circ}$ & 3.4 & 0.00119 & 7.63139 & 72.874 \\
\hline Model 1 Flaps $3 \mathrm{~cm} 15^{\circ}$ & 3.4 & 0.00112 & 7.57876 & 72.372 \\
\hline
\end{tabular}


International Journal of Marine Engineering Innovation and Research, Vol. 6(4), Dec. 2021. 246-254 (pISSN: 2541-5972, eISSN: 2548-1479)

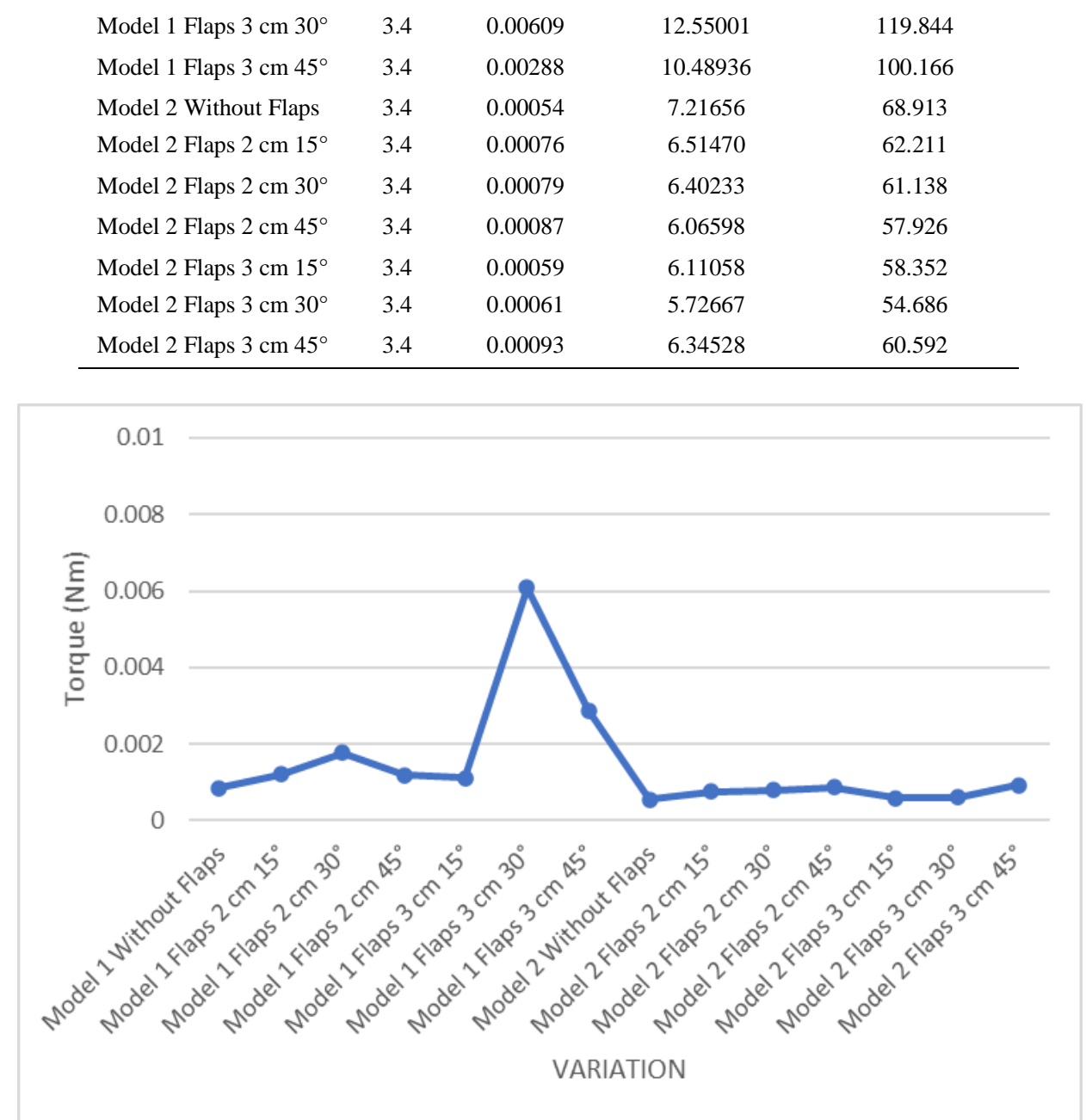

Figure. 16. Chart Result Simulation of Torque (Nm) All Variation Screw Turbine Model

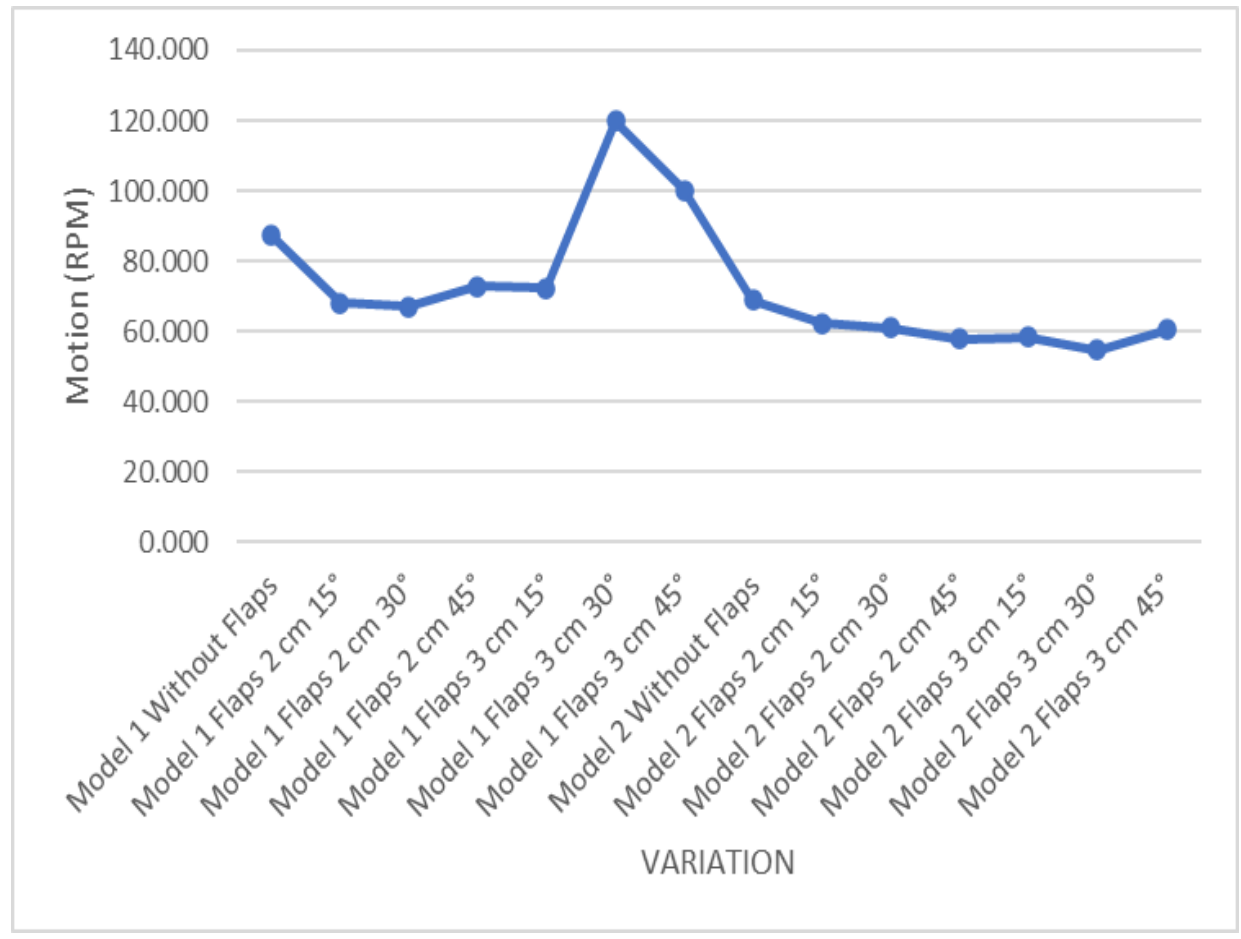

Figure. 17. Chart Result Simulation of Motion (RPM) All Variation Screw Turbine Model 


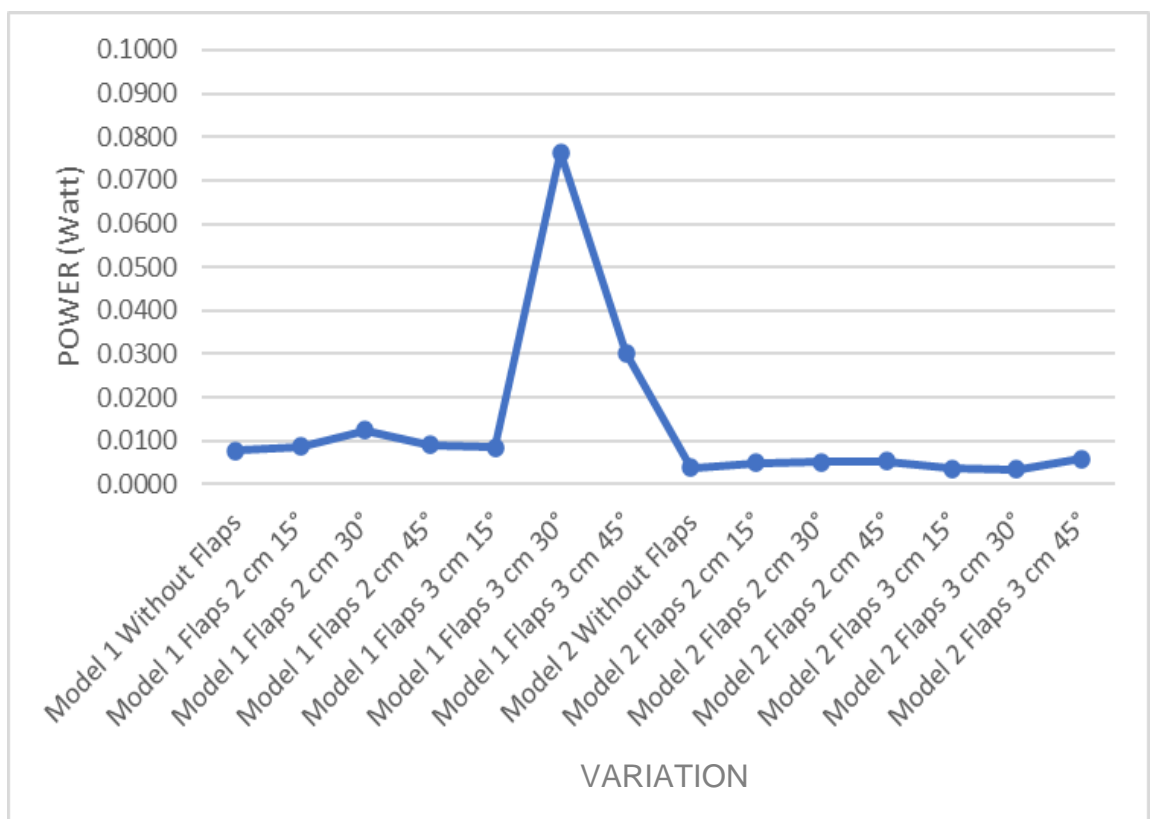

Figure. 18. Chart Result Calculation of Power (watt) All Variation Screw Turbine Model

TABLE 3.

CALCULATION PERFORMANCE SCREW TURBINE MODEL

\begin{tabular}{llccc}
\hline \multicolumn{1}{c}{ Model Variation } & $\begin{array}{c}\text { Power } \\
\text { (Watt) }\end{array}$ & $\begin{array}{c}\text { Power Coefficient } \\
\text { (CP) }\end{array}$ & $\begin{array}{c}\text { Tip Speed } \\
\text { Ratio (TSR) }\end{array}$ & $\begin{array}{c}\text { Torque Coefficient } \\
\text { (CQ) }\end{array}$ \\
\hline Model 1 Without Flaps & 0.0078 & 0.0047 & 0.4041 & 0.0116 \\
Model 1 Flaps 2 cm 15 & 0.0086 & 0.0049 & 0.3262 & 0.0149 \\
Model 1 Flaps 2 cm 30 & 0.0124 & 0.0066 & 0.3314 & 0.0199 \\
Model 1 Flaps 2 cm 45 & 0.0091 & 0.0046 & 0.3697 & 0.0124 \\
Model 1 Flaps 3 cm 15 & 0.0085 & 0.0046 & 0.3529 & 0.0131 \\
Model 1 Flaps 3 cm 30 & 0.0764 & 0.0382 & 0.6109 & 0.0625 \\
Model 1 Flaps 3 cm 45 & 0.0302 & 0.0140 & 0.5297 & 0.0265 \\
Model 2 Without Flaps & 0.0039 & 0.0024 & 0.3184 & 0.0075 \\
Model 2 Flaps 2 cm 15 & 0.0050 & 0.0028 & 0.2983 & 0.0092 \\
Model 2 Flaps 2 cm 30 & 0.0051 & 0.0026 & 0.3022 & 0.0085 \\
Model 2 Flaps 2 cm 45 & 0.0053 & 0.0028 & 0.2938 & 0.0091 \\
Model 2 Flaps 3 cm 15 & 0.0036 & 0.0020 & 0.2845 & 0.0069 \\
Model 2 Flaps 3 cm 30 & 0.0035 & 0.0018 & 0.2788 & 0.0063 \\
Model 2 Flaps 3 cm 45 & 0.0059 & 0.0027 & 0.3204 & 0.0085 \\
\hline
\end{tabular}

\section{CONCLUSION}

\section{A. Conclusion}

The Design models screw turbines 1 and 2 are proven to be able to extract wind energy by obtaining torque and angular velocity from the simulation of the model screw turbine that has been carried out.

Performance analysis of the model design screw turbine with the addition of flaps proved to be able to increase the torque value in model 1 and model 2 . In addition, pitch widening affects the torque value produced, in model 2 the pitch is wider than model 1 , the torque value is smaller. than model 1 . In this study, the highest torque and angular velocity were obtained in model 1 with the addition of $3 \mathrm{~cm}$ flaps with a $30^{\circ}$ flap angle variation with a torque value of $0.00609 \mathrm{Nm}$ and a rotation of $12.55 \mathrm{rad} / \mathrm{s}$.

\section{B. Recommendation}

For further research, various variations can be carried out such as model design (helix angle, pitch, variations in flap angle, flap size, material type), model dimensions, flow velocity, angle/direction of the wind. So it will be obtained from a turbine model that has an optimal design for extracting wind energy.

\section{ACKNOWLEDGMENTS}

Thank you to all the lecturers of the marine electrical and automation system laboratory who helped complete this research. Thanks to the members of the marine electrical and automation system laboratory.

\section{REFERENCES}

G. Dellinger et al., "Computational fluid dynamics modeling for the design of Archimedes Screw Generator," Renew. Energy, 2018, doi: 10.1016/j.renene.2017.10.093.

[2] M. Lyons and W. D. Lubitz, "ES2013-18067," no. 1999, pp. $1-7,2013$. 
[3] Japan For Sustainability (JFS), "Micro Hydropower System with Spiral Water Turbine under Development," 2008.

[4] K. Brada, "Wasserkraftschnecke ermöglicht Stromerzeugung über Kleinkraftwerke [Hydraulic screw generates electricity from micro hydropower stations].," vol. 105 , no. 14 , pp. 52-56, 1999.

[5] A. Lashofer, W. Hawle, and B. Pelikan, "State of technology and design guidelines for the Archimedes screw turbine," Int. J. Hydropower Dams, Hydro 2012 - Proc., 2012.

[6] N. A. Hidayatullah and H. N. K. Ningrum, "Optimalisasi Daya Pembangkit Listrik Tenaga Angin Turbin Sumbu Horizontal dengan Menggunakan Metode Maximum Power Point Tracker," JEECAE (Journal Electr. Electron. Control. Automot. Eng., 2017, doi: 10.32486/jeecae.v1i1.5.
[7] Suyitmadi, "Analisis Kinerja Flap Sebagai Penambah Koefisien Gaya Angkat," 2000.

[8] Y. Daryanto, "Kajian Potensi angin Untuk Pembangkit Listrik Tenaga Bayu," Blueprint, no. April, 2007.

[9] J. F. Manwell, J. G. McGowan, and A. L. Rogers, Wind Energy Explained: Theory, Design and Application. 2010.

[10] H. Jang, D. Kim, Y. Hwang, I. Paek, S. Kim, and J. Baek, "Analysis of Archimedes spiral wind turbine performance by simulation and field test," Energies, 2019, doi: $10.3390 /$ en 12244624 . 